\title{
Qualitative Assessment of the Red Wine Varieties Grown in Dealu Bujorului Vineyard
}

\author{
Florin Dumitru BORA ${ }^{1 *}$, Alina DONICI ${ }^{1}$, Aurel CIUBUCA $\breve{A}^{1}$, Elena POSTOLACHE ${ }^{1}$, Gabriel TABARANU ${ }^{1}$, \\ Viorica ENACHE ${ }^{1}$, Nicolaie BÎRLIGA ${ }^{1}$, Nastasia POP ${ }^{2}$, Claudiu BUNEA ${ }^{2}$ \\ ${ }^{1}$ Research Station for Viticulture and Enology, Targu Bujor, Galați, Romania. \\ ${ }^{2}$ Departament of Horticulture and Landscape, Faculty of Horticulture, University of Agricultural \\ Sciences and Veterinary Medicine, Cluj-Napoca, Romania. \\ *)Corresponding author, e-mail: boraflorindumitru@gmail.com
}

BulletinUASVM Horticulture 73(2) / 2016

Print ISSN 1843-5254, Electronic ISSN 1843-5394

DOI:10.15835/buasvmcn-hort:12129

\begin{abstract}
Wine is considered to be a hydro alcoholic solution with more than 1000 components associated in an extremely complex manner, some of them can pass from grapes in an unchanged state, and some are formed during alcoholic and malolactic fermentation, while others appear due to the reactions between substances in their natural state, or based on the existing ones. The presence of phenolic substances in wine is essential, representing a major contribution in the forming of specific characteristics such as: colour, aroma and taste, thus allowing the distinction between different types of wine. The main purpose of this research is to evaluate the physicochemical composition of the three acknowledged varieties of young wine from the Dealu Bujorului vineyard ('Merlot', 'Cabernet Sauvignon' and 'Fetească Neagră'), obtained under the culture conditions of 2012 - 2013 - 2014 years. The oenological parameters were determined after the national STAS regulations and effectively OIV methods. Statistical methods were employed in order to assess the organic and inorganic potential of wine. The ecoclimatic conditions studied in the Dealu Bujorului, Bujoru Wine Centre, highlighted the exceptional viticultural character of Romania as well as the authenticity character encountered in the large variety of wines produced in this area. Results also show that the vine varieties of cultivated in the Vineyard of Dealu Bujorului have a high content of macroelements (potassium, calcium) ('Merlot' (890.01 $\pm 6.35 \mathrm{mg} / \mathrm{L}$ (2013)), 'Cabernet Sauvignon' (111.36 23.53 $\mathrm{mg} / \mathrm{L}(2013)$ ) and 'Feteasca neagră' (97.30 $\pm 0.46 \mathrm{mg} / \mathrm{L}$ (2014)) that are very important for human's health. Wine quality parameters analyzed shows that are influenced by the area of culture of vine but also they are influenced by the technology of winemaking.
\end{abstract}

Keywords: quality, red wine, spectrophotometer method, vine, Vitis vinifera

\section{INDRODUCTION}

The world of grapes and wines concerns at least 40 countries, the quality and the typeness of wines depend on natural ecoclimatic and human factors. It said that, worldwinde the climate of the different grape growing regions accounts for a large part of the difersity of varieties cultivated, quality and typeness of the wines and viticultural products (Tonietto and Carbonneanu, 2004).

Although wine is fermented grape juice, it differs from it not only through its aroma, taste and density, but also through the chemical composition. Its composition is influenced by a series of factors related to the specific area of production, such as: grape variety, ecoclimatic conditions, grapes' ripening and technology of the wine making process (Gonzálvez et al., 2009; Torre et al., 2006; Bora et al., 2014b; Bora et al., 2015; Bora et al., 2016). For these exact reasons, there is an increasing trend to study the composition of wine in his minor constituents in order to achieve a better characterization, thereby helping to improve the commercial value of the product.

The grapevine is cultivated all over the world, Europe has the highest percentage $51 \%$ of the global surface cultivated with vine, followed by 
Africa, America and Asia countries (Gonçalves da Silva et al., 2008). Worldwide in 2013, area harvested it vine was 7455187.00 hectares, and there was a production of 77181122.00 tonnes (FAO). The wine groing area in Romania has decreased since the 1990, curently it ranks fifth in Europe after countries France, Spain, Italy and Portugal (Bora et al., 2014a).

The favorable climatic conditions for viticulture are divided in two parts: vital conditions for viticulture and natural critical conditions. The vital conditions are very important and directly influences the growth and fructification of the grapevines, the factors worth being mentioned are as follows: solar radiation, temperature, light and also humidity, the vegetation period precipitations in the growing season and the interaction of these factors (Hydrothermal coefficient $(\mathrm{CH})$ ), Heliothermal real index (IHr)), Bioclimatic vineyard index (Ibcv)), Oenoclimatic skills index (IAOe)). The natural critical conditions, aversely affect the growth and fructification of the vine, resulting in a decreased production both in terms of quality and quantity (Pop, 2010). The quality of grapes is also directly influenced by ecoclimatic conditions, variety, the level of applied agrotechnical works, zoning (Bunea, 2010; Condurso et al., 2015; Rotaru et al., 2010).

During the ripening period the air temperature plays an important role for the grape maturation, including the coloration, the aroma, also heaving an important effect on the characteristic of wines (Jankson and Lombard, 1993; Tonietto and Carbonneau, 2004). The day temperature and cool nights influence the coloration (Singleton and Esau, 1969; Kliewer and Torres, 1972; Kliewer, 1973; Fregoni and Pezzutto, 2000).

The presence of phenolic substances in wine is fundamental, they have a major contribution to the formation of specific characteristics such as: colour, aroma and taste, that distinguishes the types of wine (Mitic et al., 2010). The polyphenolic mark and elemental composition are a useful tool for classifying wines (Avar et al., 2007; Di PaolaNaranjo et al., 2011; Geana et al., 2011; Geana et al., 2013).

Soil is one of the most important factors of the production area which shows a particular interest for the assessment of the environmental effects on the mineral composition of the vine (Bora et al., 2014a; Meghesan-Breja et al., 2014;
Meghesan-Breja et al., 2012). In the ongoing effort to develop monitoring techniques of the wine, geochemical marks significantly improve the traceability of wines to their origins, especially the mineral compositions of vines and their products are covered by soil characteristics and cultivation practices.

Different water level in soil affects quality and quantity (Conradie et al., 2002). Jackson and Cherry (1988) show that in areas with a high rainfall the ripening capacipity of grapes is lower to that predicted by climatic thermal indices. It is observed that in temperate areas which do not generally suffer droughts, a certain lack of water during the ripening periof is favorable to the organoleptic wine quality (Galet, 1993; Riou et al., 1994; Huglin and Schneider, 1998).

Quality is also influenced by the winemaking practices such as fermentation temperature, duration of contact with skin and aging in barrels. In the red wine production, the maceration time is often prolonged and occurs along with alcoholic fermentation. The enzymatic activity promotes maceration and alcohol concentrations increase during the maceration process which involves both the ethanol extraction as well as ethanolysis. The increased level of ethanol in wine best contributes to the solubilizing of pigments (anthocyanin compounds) and of tannins. These compounds give a red colour and a flavour of maturity to the wine (Jackson, 2003).

\section{MATERIAL AND METHOD}

The purpose of this research is to trace the quality of the red wines from Dealu Bujorului in the ecoclimatic conditions of the years 2012 - 2013 - 2014. This paper presents data on the compositional characteristics of wines such as alcohol, total acidity, volatile acidity, non-reducing extract, reducing sugar, free and total dioxide, non-reducible extract, $\mathrm{pH}$, acetic acid, potassium, calcium, alfa-amino nitrogen, tartaric acid, L-malic acid, cupper, iron, L-lactic acid, D-gluconic acid and also glycerol. As representative vine varieties to Dealu Bujorului vineyard the following vine varieties were chosen: 'Merlot', 'Cabernet Sauvignon' and 'Fetească Neagră', from 2015 wine production in the culture conditions of the Dealu Bujorului vineyard. The wine samples were obtained under microwine production. Fifty kilograms of grapes were destemmed and crushed 
than transferred to a microfermentator $(20 \mathrm{~L}$ clyndrical glass container, cover with alumium foil), grapes were harvested on September 21, 2015. Fermentation took place at $25{ }^{\circ} \mathrm{C}$ and humidity of 58-60.

To characterize the researched area, the weather data used was recorded from Agro Expert system of RSDVV Bujoru. Based on this data, the ecoclimatic important indicators for the grapevine are determined: $\left(\sum \mathrm{t}^{\circ} \mathrm{g}\right)$ global thermal balance; $\left(\sum \mathrm{t}^{\mathrm{o}} \mathrm{a}\right)$ active balance; useful thermal balance $\left(\sum \mathrm{t}^{\mathrm{o}} \mathrm{u}\right)$; ( $\Sigma$ annual precipitations $(\mathrm{mm})$ ) amount of annual precipitation; ( $\mathrm{ir}$ ) annual hours of insolations. In order to get a clearer picture about how climatic factors influence the growth and fruition of the grapevines, the helioclimatic index (HI), hydrothermal coefficient $(\mathrm{CH})$, Heliothermal real index, (IHr), Bioclimatic vineyard index, (Ibcv) and bioclimatic vineyard index were calculated.

The physico-chemical analyses of wine were performed in the Laboratory of Winemaking of the RSDVV Bujoru, this methods of analysis was described in Postolache et al., (2016).

The statistical interpretation of the results was performed using the DUNCAN test, using the SPSS, version 24 (SPPS Inc. Chicago, IL, USA). The statistical processing of the results was primarily made to calculate the following statistical parameters: arithmetic average, standard deviation, average error, using the statistical package SPSS version 24 (SPPS Inc. Chicago, IL, USA). The data were interpreted by variance analysis (ANOVA), the separation of environments was performed using the DUNCAN test at $p \leq 0.005$. The interaction between variety and year was evaluated by selecting $\mathrm{p} \leq 0.0001, \mathrm{p} \leq 0.001$ and $\mathrm{p} \leq 0.005$ in order to determine the significance.

\section{RESULTS AND DISCUSSIONS}

Climatic conditions of the aresearched area. Analysis of the main ecoclimatic conditions in the overall climate of the period 2012-2014 compared to the average multiannual highlights the following: (1) increasing the average temperatures during the growing seasen in 2012 from $19.4^{\circ} \mathrm{C}$ to $21.0^{\circ} \mathrm{C}$; (2) increasing the average temperatures in july, august and september in 2012; (3) reduction precipitation during the growing season; (4) increasing the number of days with temperatures above $30^{\circ} \mathrm{C}$, in 2012 (70), 2013 (26) and 2014 (35); (5) hydrothermal coefficient,
$(\mathrm{CH})$ ranged between 0.59 and 1.57, falling within the limits described in the literature (0.7 to 1.8), indicating that the moisture was sufficient; (6) Heliothermal real index, (IHr) ranged between 2.0-3.12, higest that the average multiannual 2.31 which shows an increase in thermal resources and optimal riping of late varieties; (7) oenoclimatic skills index (IAOe) indicates that this area are mainly for the production of red and white wines.

The climatic conditions studied in Bujoru Wine Centre, Dealu Bujorului vineyard, show the exceptional viticultural character of Romania, and the authenticity one, encountered in a large variety of wines produced in the studied areas.

Analysis of the main quality parameters of red wine in the Dealu Bujorului Vineyard, Bujoru Wine Centre. When analysing each variety, can be noted that the obtained wines presented a variable alcohol content (Tab. 2). The differences between the versions were statistically displayed $(\mathrm{F}=356.729, \mathrm{p}$ ? 0.000). The wine produced in 2012 from the 'Merlot' variety (16.03\% vol.), followed by the wine produced in 2014 from 'Fetească Neagră' (15.90\% vol.) recorded the highest alcoholic concentration when compared to the other varieties under testing; these varieties are equal in terms of statistics. The lowest level of alcohol was recorded in the wines obtained from varieties: 'Merlot' (13.60\% vol. in 2013); 'Cabernet Sauvignon' (14.30\% vol. in 2013; $14.20 \%$ vol. in 2014); and 'Fetească Neagră' (12.83\% vol. in 2012; $12.50 \%$ vol. in 2013).

The interaction between the two factors variety $\mathrm{x}$ year $(\mathrm{F}=406.789, \mathrm{p}$ ? 0.000) had the greatest influence on the alcoholic degree, followed by the factor year $(F=415.743, p$ ? 0.000) and variety $(\mathrm{F}=197.600, \mathrm{p}$ ? 0000), which had a very significant influence on the alcoholic degree. The alcoholic concentration of the wines 'Merlot', 'Cabernet Sauvignon' from 2012 recorded higher values (16.03 and 15.20) and 'Fetească Neagră' from 2014 recorded $15.90 \%$ vol. alcohol, as a result of sugars' accumulation during the grapes' ripening.

Regarding the total acidity $\left(\mathrm{g} / \mathrm{L} \mathrm{C}_{4} \mathrm{H}_{6} \mathrm{O}_{6}\right)$, it can be seen that this parameter was very significantly influenced by the interaction between the two factors variety x year $(F=261.086, p \leq 0.000)$, by variety $(F=139.276, p \leq 0.000)$, followed by the year factor $(F=22.483, p \leq 0.000)$. The differences 
Tab. 1. Ecoclimatic conditions in Dealu Bujorului

\begin{tabular}{|c|c|c|c|c|}
\hline Climate conditions & $\begin{array}{c}\text { The multiannual } \\
\text { average* }\end{array}$ & 2012 & 2013 & 2014 \\
\hline Thermal balance Global $\left(\sum \mathrm{t}^{0} \mathrm{~g}\right)$ & 3532 & 3837.8 & 3382.9 & 3321.9 \\
\hline Thermal balance Active $\left(\sum \mathrm{t}^{0} \mathrm{a}\right)$ & 3473 & 3781.5 & 3295.2 & 3220.3 \\
\hline Thermal balance Useful $\left(\sum \mathrm{t}^{0} \mathrm{u}\right)$ & 1757 & 2031.5 & 1575.2 & 1520.3 \\
\hline The average temperature in July $\left({ }^{\circ} \mathrm{C}\right)$ & 24.1 & 28 & 21.5 & 22.1 \\
\hline The average temperature in August $\left({ }^{\circ} \mathrm{C}\right)$ & 23.1 & 26.4 & 22.2 & 22.3 \\
\hline The average temperature in September $\left({ }^{\circ} \mathrm{C}\right)$ & 17.5 & 20.7 & 15 & 17 \\
\hline The average annual temperature $\left({ }^{\circ} \mathrm{C}\right)$ & 11.5 & 11.6 & 11.1 & 10.8 \\
\hline The average temperature during the growing season $\left({ }^{\circ} \mathrm{C}\right)$ & 19.4 & 21 & 18.5 & 18.1 \\
\hline The absolute minimum temperature $(\stackrel{o}{\mathrm{o}})$ & -25.5 & -23.6 & -17.3 & -20.5 \\
\hline The absolute maximum temperature $\left({ }^{\circ} \mathrm{C}\right)$ & 41.5 & 41.5 & 35.1 & 35.8 \\
\hline Number of days with temperatures above $30^{\circ} \mathrm{C}\left({ }^{\circ} \mathrm{C}\right)$ & 38.4 & 70 & 26 & 35 \\
\hline$\Sigma$ annual insolation, (hours) & 1761.1 & 2096.4 & 1930.6 & 1679.1 \\
\hline$\sum$ hours of insolation in the growing season (hours) & 1315.8 & 1535.8 & 1520.9 & 1337 \\
\hline$\sum$ annual precipitations (mm) & 455.9 & 448 & 713.1 & 450.8 \\
\hline$\sum$ precipitations in the growing season (mm) & 296 & 223 & 516 & 258 \\
\hline The vegetation period, (days) & 179.8 & 197 & 171 & 182 \\
\hline Hydrothermal coefficient, $(\mathrm{CH})$ & 0.85 & 0.59 & 1.57 & 0.8 \\
\hline Heliothermal real index, (IHr) & 2.31 & 3.12 & 2.4 & 2.03 \\
\hline Bioclimatic vineyard index, (Ibcv) & 8.58 & 13.2 & 5.7 & 9.2 \\
\hline Oenoclimatic skills index (IAOe) & 4742.8 & 5344.3 & 4550.1 & 4549.3 \\
\hline
\end{tabular}

between the versions were statistically displayed $(\mathrm{F}=170.983, \mathrm{p} \leq 0.000)$. The highest values were recorded for the wine produced from 'Cabernet Sauvignon' variety in $2012\left(8.17 \mathrm{~g} / \mathrm{L} \mathrm{C}_{4} \mathrm{H}_{6} \mathrm{O}_{6}\right)$; in the opposite, the lowest value of total acidity was recorded in the wine produced from the 'Fetească Neagră' variety in $2012\left(5.43 \mathrm{~g} / \mathrm{L} \mathrm{C}_{4} \mathrm{H}_{6} \mathrm{O}_{6}\right)$. Along with the alcohols, the wine acids are the main factors for the conservation of wines. All red wines studied did not perform malolactic fermentation, except for 'Fetească Neagră' from 2012.

In the case of volatile acidity $\left(\mathrm{g} / \mathrm{L} \mathrm{CH}_{3} \mathrm{COOH}\right)$, (Tab. 2) it can be seen from the presented data, that this parameter recorded variables values for the analysed variants. The highest values were registered in the wine produced in 2012 from the 'Merlot' variety $\left(0.63 \mathrm{~g} / \mathrm{L} \mathrm{CH}_{3} \mathrm{COOH}\right)$, followed by the wine produced from 'Fetească Neagră' $(0.60$ $\mathrm{g} / \mathrm{L} \mathrm{CH}_{3} \mathrm{COOH}$ ). The lowest values were recorded wine produced from 'Fetească Neagră' $(0.34 \mathrm{~g} / \mathrm{L}$ $\mathrm{CH}_{3} \mathrm{COOH}$ ) in 2013. In terms of years of culture can be seen from the given data that the highest values of volatile acidity were recorded in 2012, and the lowest ones in years 2013 and 2014. The differences between the versions were statistically displayed $(\mathrm{F}=249.781, \mathrm{p} \leq 0.000)$. The factor year $(\mathrm{F}=540.875, \mathrm{p} \leq 0.000)$ had the greatest influence on this character, followed by variety factor $(\mathrm{F}=$ $169.906, \mathrm{p} \leq 0.000$ ) and the interaction of the two factors variety $\mathrm{x}$ year had a significant influence on the total acidity ( $\mathrm{F}=144.172, \mathrm{p} \leq 0.000)$.

The volatile acidity represents the most important factor for the preservation of wine, for assessing the quality and health control of the wine and recorded values within normal limits in all varieties (0.34 - 0.63) g/L acetic acid.

Regarding the content of free sulphur dioxide $\left(\mathrm{SO}_{2}\right)$ in wine, the highest concentration was registered in the wine produced from 'Merlot' (29.00 mg/L in 2012), followed by 'Cabernet Sauvignon' (26.47 mg/L in 2014). The lowest values were obtained in the varieties: 'Merlot' (18.00 mg/L in 2013, $18.39 \mathrm{mg} / \mathrm{L}$ in 2014), 'Cabernet Sauvignon' (19.00 mg/L in 2012, 18.66 mg/L in 2013) and 'Fetească Neagră' (18.00 mg/L in $2012,18.33 \mathrm{mg} / \mathrm{L}$ in $2013,18.97 \mathrm{mg} / \mathrm{L}$ in 2014 ), 
the values are equal in terms of statistics. All the studied factors had a very significant influence on this character. Reporting the obtained results to the effective legislation, regarding the content of free $\mathrm{SO}_{2}$, it can be seen that all the produced wines have a much lower content than that provided in the national law, therefore, the obtained wines can be consumed or available for preserved.

The highest amount of total $\mathrm{SO}_{2}$ was recorded in the wine produced from 'Fetească Neagră' (140.67 $\mathrm{mg} / \mathrm{L}$ in 2012), followed by 'Merlot' (121.67 mg/L in 2013). The lowest values of total $\mathrm{SO}_{2}$ were recorded at 'Fetească Neagră' (59.67 $\mathrm{mg} / \mathrm{L}$ in 2014), and this value is much lower than in the other studied years $(140.67 \mathrm{mg} / \mathrm{L}$ in 2012 and $108.67 \mathrm{mg} / \mathrm{L} \mathrm{2013).} \mathrm{All} \mathrm{the} \mathrm{studied} \mathrm{factors}$ have very significantly influenced this character. The amount of free and total sulphur dioxide in the produced wines is within normal range. Sulphur dioxide represents the main antiseptic that can inhibit the activity of microorganisms in must and wine. Likewise, sulphur dioxide is a powerful reducing agent, it can protect musts and wines against oxidation, therefore, and its antioxidant activity is to destroy enzymes that catalyse the oxidation of certain substances.

The residual sugar are small and variable amounts, usually between 5-80 g/L. Dry wines contain 2-3 g/L this amount dows not endanger the preservation of wine. The amounts of $2-5 \mathrm{~g} / \mathrm{L}$ of sugar, give a smoother taste and easier appreciable density, more than $5 \mathrm{~g} / \mathrm{L}$ of sugar makes the wine to acquire a sweet clean taste, and the presence of sugars makes it fragile to microorganisms. We can see that the analysed varieties present significant differences $(\mathrm{F}=2181.653, \mathrm{p} \leq 0.000)$.

The 'Cabernet Sauvignon' variety displayed the highest sugar content $(20.77 \pm 0.67(\mathrm{mg} / \mathrm{L})$ 2012), followed by varieties Feteasca neagră (12.40 $\pm 0.23(\mathrm{mg} / \mathrm{L}) 2014)$ and 'Cabernet Sauvignon' $(10.62 \pm 0.15(\mathrm{mg} / \mathrm{L}) 2014)$. Years factor had a very significant influence $(\mathrm{F}=7645.905, \mathrm{p} \leq 0.000)$, followed by variety factor $(F=421.149, p \leq 0.000)$ also had very significant influence. In this case the interaction of the two factors (variety $\mathrm{x}$ yeas) had a very significant influence on this character $(\mathrm{F}=$ 896.277, $\mathrm{p} \leq$ 0.000) (Tab.2).

The content of unreducible extract recorded values higher than $34.90 \mathrm{~g} / \mathrm{L}$ on the wine produced from the 'Cabernet Sauvignon' variety in the year of culture of 2012, followed by 'Merlot' (33.13
g/L) in 2012 and 'Fetească Neagră' (31.57 g/L) in 2012; these values are equal in terms of statistics. At the opposite, the lowest values of the extract unreducible were recorded in the wine produced in 2013 from 'Cabernet Sauvignon' (24.43 g/L), followed by 'Merlot' (26.87 g/L) and 'Fetească Neagră' (26.87 g/L) which are equal in statistical terms. The differences between the versions were statistically displayed ( $\mathrm{F}=780.767, \mathrm{p}$ ? 0.000$)$. The two factors (variety $\mathrm{x}$ year), and also the interaction between the two had a very significant influence on this character (Tab. 2).

The unreducible extract consists of all wine substances that certain physical conditions do not volatilize, but remain as a residue. The 2012 wines have a high degree of extraction, namely, the 'Merlot' variety $33.13 \mathrm{~g} / \mathrm{L}$, 'Cabernet Sauvignon' 34.90 g/L and 'Fetească Neagră' 31.57 g/L. The content of unreducible extract in the 2013 wines is lower in all studied varieties, ranging from 24.43 $\mathrm{g} / \mathrm{L}$ in 'Cabernet Sauvignon' to 26.87 in 'Merlot' and 'Fetească Neagră'.

The highest $\mathrm{pH}$ level was obtained in the wine produced from 'Fetească Neagră' (3.64 in 2012 and 3.61 in 2014), the values are equal in terms of statistics. At the opposite, the wine produced from 'Fetească Neagră' in 2013 (3.21) and 'Cabernet Sauvignon' 2012 (3.20) recorded the lowest values, which are equal in terms of statistics. The differences between the versions were statistically displayed $(\mathrm{F}=185.087, \mathrm{p}$ ? 0.000 ) (Tab. 2). The year factor ( $\mathrm{F}=274.862$, $\mathrm{p}$ ? 0.000 ) had the greatest influence on this character. Real acidity, or $\mathrm{pH}$, is also known as ionic acidity of the wine and measures the difference of potential between two electrodes immersed in the sample. Depending on the $\mathrm{pH}$ value, the wines present a pleasant taste, vivid colour, resistance to bacteria and better preservation.

As it is formed in wine, the acetic acid hinders the activity of the yeasts fermentation, on the other hand, the acetic acid has the greatest contribution to the formation of the wine's volatile acidity, affecting, thus, the quality of the wine. Although a weak acid, it has a great activity in wine. It imprints the taste of "vinegar" when its concentration exceeds $0.7-1.0 \mathrm{~g} / \mathrm{L}$. The highest concentrations of acetic acid $(\mathrm{g} / \mathrm{L})$ were recorded in the 'Merlot' variety $(0.51 \pm 0.03$ (g/L) 2012), followed by the same variety $(0.47 \pm 0.01(\mathrm{~g} / \mathrm{L})$ 2013), while 'Cabernet Sauvignon' variety (0.38 \pm 
$0.51(\mathrm{~g} / \mathrm{L}) 2013 ;(0.40 \pm 0.63) 2014)$ and have a lower acetic acid level.

In a normal state, wine contains $0.4-1.5$ g K/L (Țârdea, 2007), most often in the form of KHT (bitartrate) which deposits. In a free state, the concentration of potassium are lower (Chardonnay wines from the Murfatlar Vineyard contain 410 - $496 \mathrm{mg} \mathrm{K} / \mathrm{L}$, while the Sauvignon 640 - $710 \mathrm{mg} \mathrm{K} / \mathrm{L}$; the red wines from Uricani-Iași contain 680 - 1125 mg K/L) (Țârdea, 2007). The increasing of wine amounts of potassium is due to irrigation, the use of chemical potassium fertilizers and to the addition of potassium metabisulfite in the wine that can reach up to $3.5-7.0 \mathrm{~g}$ of potassium bitartrate/L (Țârdea, 2007). Based on the presented data it can be seen that potassium is found in high amounts in wine.

Regardin the concentration of potassium highest was recorded in the 'Cabernet Sauvignon' variety $(1257.67 \pm 4.02(\mathrm{mg} / \mathrm{L}) 2014)$, followed by the 'Fetească Neagră' variety $(1165.33 \pm 15.01$ $\mathrm{mg} / \mathrm{L}$ (2013)), the lowest concentrations was recorded in the varieties 'Merlot' (848.67 \pm 3.56 (mg / L) 2014) and 'Merlot' (890.01 \pm 6.35 (mg/L) 2013). It can be stated that the tested varieties of vines had a high influence on the accumulation of $\mathrm{K}$ in wine. The differences were statistically displayed $(\mathrm{F}=19.206, \mathrm{p} \leq 0.000)$. The concentration of the potassium was within normal limits compared with the national and international data.

Calcium is a natural component of wine and it accumulates in the grapes until the ripening, the amounts are low, between $50-200 \mathrm{mg} \mathrm{Ca} / \mathrm{L}$ in must. Wine always contains less calcium than must, because alcohol contributes to the insolubilization of calcium tartrate (Târdea, 2007). White wines have a higher level in calcium than red wines and are likely to forming tartaric deposits (the red wines of Uricani-Iași have a calcium content of 56 - $88 \mathrm{mg} / \mathrm{L}$, and the white wines of Bucium - Iași 78 - $98 \mathrm{mg} / \mathrm{L}$ ) (Țârdea, 2007). Generally, red wines heave $20-30 \%$ lower content of calcium that white wines (Țârdea, 2007).

As far as that goes the calcium concentration in wine, the varieties 'Cabernet Sauvignon' (115.36 $\pm 4.01(\mathrm{mg} / \mathrm{L}) 2012)$ followed by the same variety (111.36 $\pm 3.53(\mathrm{mg} / \mathrm{L}) 2013)$ reached the highest concentration compared to the varieties 'Merlot' (90.61 $\pm 0.83(\mathrm{mg} / \mathrm{L}) 2013)$ and 'Merlot' (77.86 $\pm 2.31(\mathrm{mg} / \mathrm{L}) 2012)$ which recorded the lowest concentration of this macroelement.
The lowest values of the concentration of amino nitrogen were recorded in 'Fetească Neagră' variety (12.52 $\pm 0.16(\mathrm{mg} / \mathrm{L}) 2014)$ and 'Merlot' varieties (13.78 $\pm 0.19(\mathrm{mg} / \mathrm{L})$ 2014), while 'Cabernet Sauvignon' (35.86 \pm 0.74 (mg/L) 2014) registered the highest values. The differences between varieties were statistical $(F=843.766$, $\mathrm{p} \leq 0.000)$. We can see that the variety factor had a very significant influence $(F=3991.001, p$ $\leq 0.000$ ), followed by the interaction of the two factors (variety x yeas) had also a very significant influence on this character $(\mathrm{F}=169.716, \mathrm{p} \leq$ $0.000)$, and years factor $(F=62.654, p \leq 0.000)$ had very significant influence.

The tartaric acid is also known as „vinic acid” because is only formed in the green vine organs. It is the most abundant and important acid in wine and grapes (65-70\%) of the total acids. Starting from the must and up to the bottling of wine, the content of tartaric acid is continuously decreasing, and during the alcoholic fermentation, as the ethyl alcohol is being formed, about $50-60 \%$ of the must's tartaric acid has been deposited in the form of salts; the precipitation and deposition of potassium tartrate continues (KHT). Kept at cellar's temperature, the white wines contain 6 $30 \mathrm{mg} / \mathrm{L}$ of soluble tartrate and red wines 12 - 40 $\mathrm{mg} / \mathrm{L}$.

The 'Merlot' variety recorded the highest concentration of tartaric acid $(1.89 \pm 0.05(\mathrm{~g} / \mathrm{L})$ 2013), followed by 'Fetească Neagră' (1.78 \pm 0.04 (g/L) 2013), the lowest concentration of tartaric acid was registered in the 'Cabernet Sauvignon' variety $(1.53 \pm 0.05$ (g/L) 2013), followed by Fetească regală variety $(1.56 \pm 0.14(\mathrm{~g} / \mathrm{L}) 2012)$. The difference between the varieties was statistical $(\mathrm{F}=21.338, \mathrm{p} \leq 0.000)$ (Tab. 1). We can see that the variety years factor had a very significant influence $(\mathrm{F}=67.297, \mathrm{p} \leq 0.000)$, followed by variety factor $(\mathrm{F}=12.636, \mathrm{p} \leq 0.000)$ also had very significant influence. In this case the interaction of the two factors (variety $\mathrm{x}$ yeas) it has no influence on this character $(\mathrm{F}=0.201, \mathrm{p}=0.934)$.

Regarding the iron content of wine, the highest concentration of iron was recorded in 'Fetească Neagră' variety $(0.54 \pm 0.02(\mathrm{mg} / \mathrm{L})$ 2014), and 'Cabernet Sauvignon' variety $(0.51 \pm$ 0.06 (mg/L) 2014). At the opposite pole the lowest concentration of iron was recorded in 'Merlot' $(0.38 \pm 0.69(\mathrm{mg} / \mathrm{L}) 2013)$ and 'Merlot' varieties $(0.36 \pm 0.14(\mathrm{mg} / \mathrm{L})$ 2012). The differences 


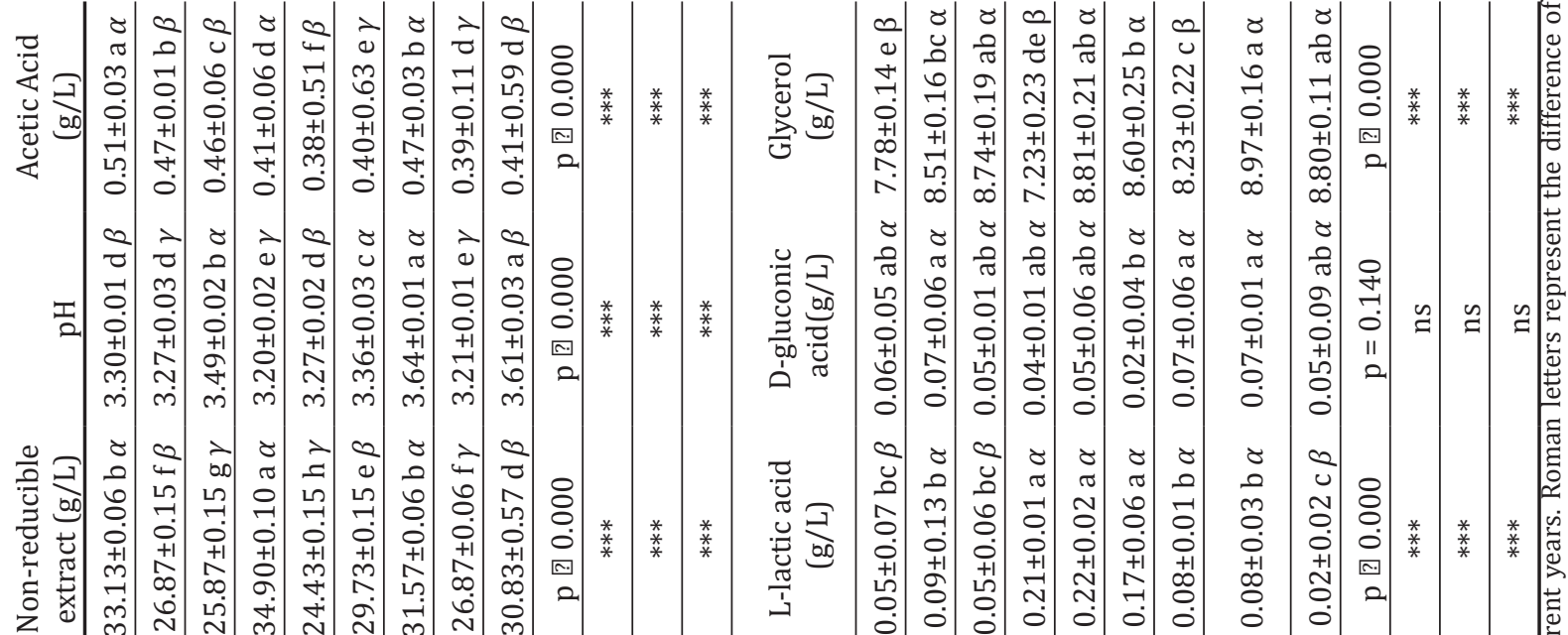

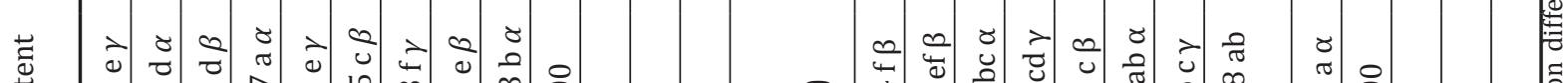

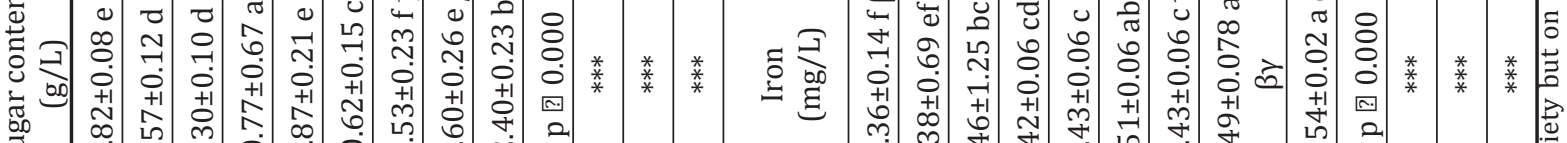

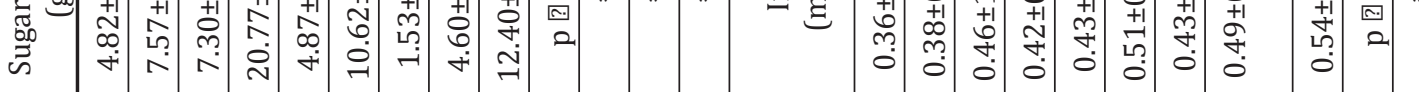

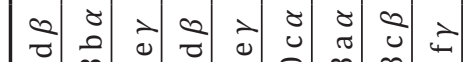

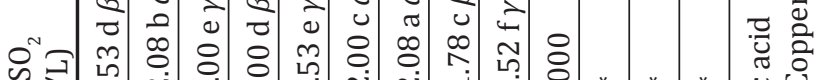

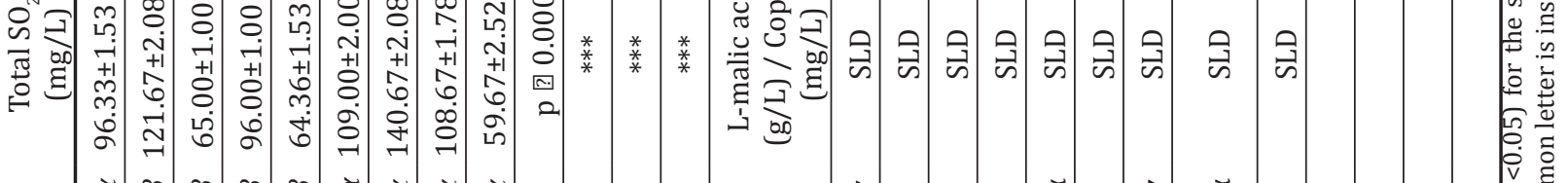

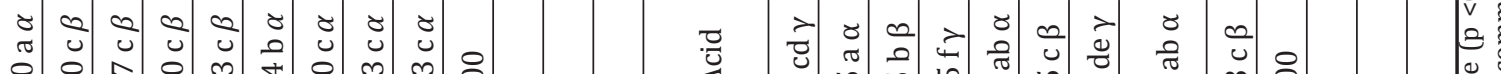

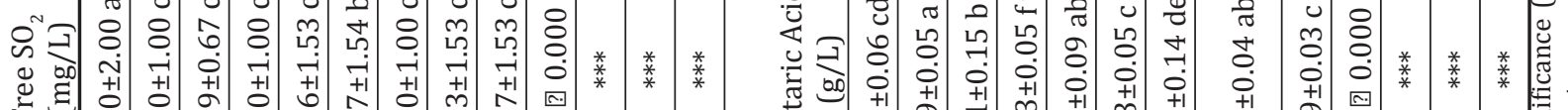

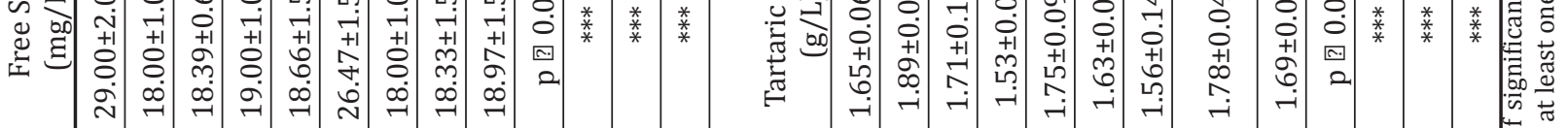

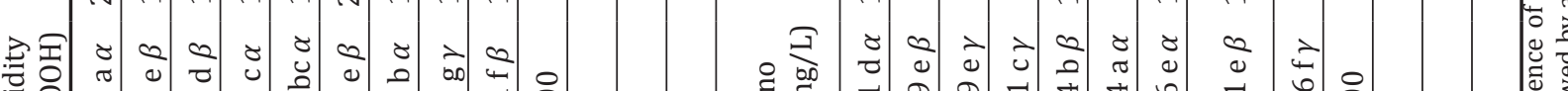

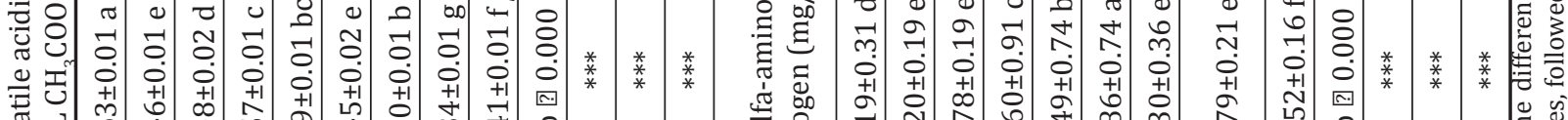

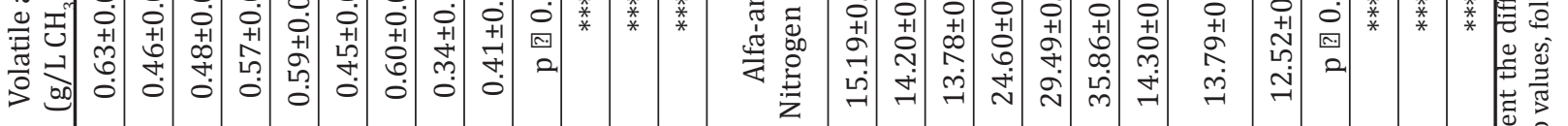

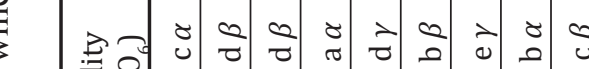

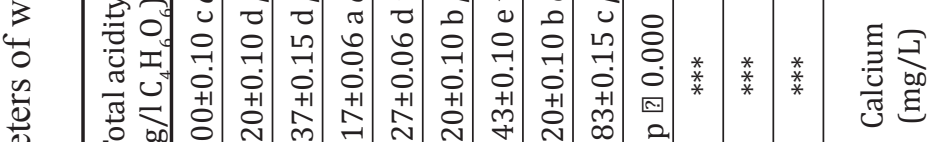

焉

气

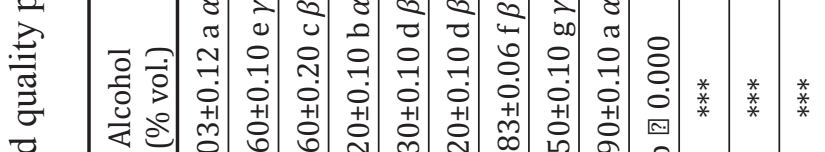

工

总

离

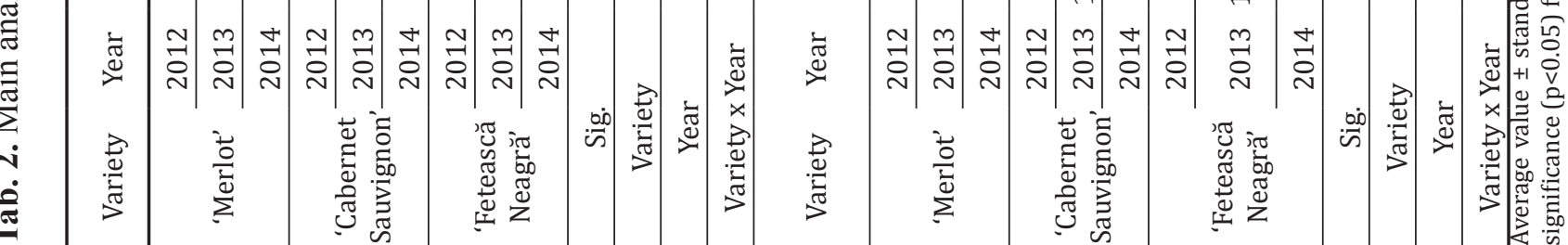

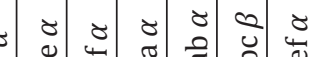

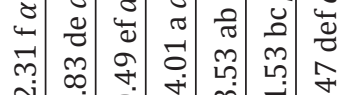

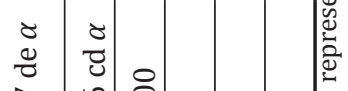

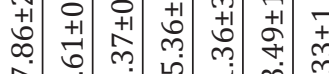

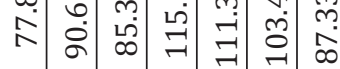

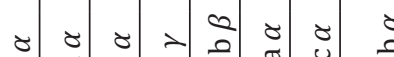

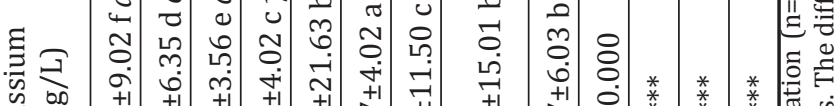

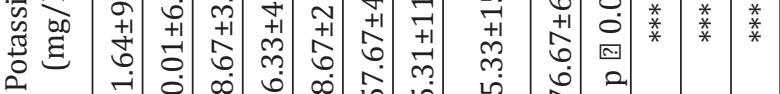

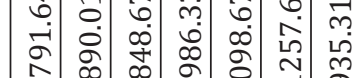

นึ

节

要

$\frac{0}{0}$

है

拿

를

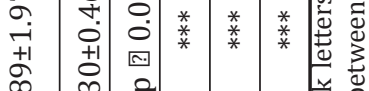

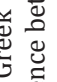

贾

这

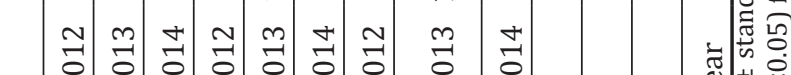


between the varieties were statistical $(\mathrm{F}=12.645$, $\mathrm{p} \leq 0.000$ ).

Regarding the L lactic acid content of the tested wines, based on the results, we can state that the highest L lactic acid content was recorded in the 'Cabernet Sauvignon' variety $(0.21 \pm 0.01$ (g/L) 2012); (0.22 \pm 0.02 (g/L) 2013); (0.17 \pm 0.06 $(\mathrm{g} / \mathrm{L}) 2014)$ these variants are equal in statistical terms. The lowest of the $L$ lactic acid was recorded in 'Merlot' variety $(0.09 \pm 0.13(\mathrm{~g} / \mathrm{L}) 2013)$ and 'Fetească Neagră' variety $(0.02 \pm 0.02$ (g/L) 2015). It can also be seen that between the studied variants, the differences were significant $(F=26.219$, $\mathrm{p} \leq 0.000$ ) (Tab. 2).

The highest concentration of d-gluconic acid $(\mathrm{g} / \mathrm{L})$ was registered in the 'Merlot' variety $(0.07$ \pm 0.06 (g/L) 2013), followed by 'Fetească Neagră' variety $(0.07 \pm 0.06(\mathrm{~g} / \mathrm{L}) 2013)$ and the same variety $(0.07 \pm 0.01(\mathrm{~g} / \mathrm{L}) 2014)$ which, in terms of statistics are equal; in contrast, the lowest concentration was recorded in 'Cabernet Sauvignon' variety $(0.02 \pm 0.04(\mathrm{~g} / \mathrm{L}) 2014)$. There are no difference between the varieties $(\mathrm{F}=1.715, \mathrm{p}=0.140)$ (Tab. 2).

Glycerol concentration in wine is between values of $5 \mathrm{~g} / \mathrm{L}$ and $15 \mathrm{~g} / \mathrm{L}$, after water and alcohol, glycerol is most abundant in wine, this concentration depends on the health of the crop and type of wine (dry or sweet). The wines from Tokoj, Hungary it has a high concentration of glycerol, reaching up to $27 \mathrm{~g} / \mathrm{L}$ and also the wines produced using high dosages of $\mathrm{SO}_{2}$ in the processing of grapes. The large concentration of glycerol formed during the fermentation process contributes to maintaining the redox balance of the wine and to the osmotic stress adjustment of yeast in the case of sugars abundant from musts. The 'Fetească Neagră' variety recorded the highest concentration in glycerol $(8.97 \pm 0.16$ (g/L) 2013), followed by 'Merlot' variety $(8.74 \pm 0.19$ (g/L) 2014), 'Cabernet Sauvignon' variety $(8.81 \pm 0.21$ (g/L) 2013) and 'Fetească Neagră' variety (8.80 $\pm 0.11(\mathrm{~g} / \mathrm{L}) 2014)$, which are equal in terms of statistics. The lowest concentration of glycerol was registered in the 'Merlot' variety (7.78 \pm 0.14 (g/L) 2012). The difference between the varieties was statistical $(\mathrm{F}=15.151, \mathrm{p} \leq 0.000)$ (Tab. 2).

\section{CONCLUSION}

The ecoclimatic conditions studied in the Dealu Bujorului, Bujoru Wine Centre, reveals the exceptional viticultural character of Romania as well as the authenticity character encountered in the large variety of wines produced in this area. Analysis of the main ecoclimatic conditions in the overall climate of the period 2012-2014 compared to the average multiannual reveals the following: (1) increasing the average temperatures during the growing season in 2012 from $19.4^{\circ} \mathrm{C}$ to $21.0^{\circ} \mathrm{C}$; (2) increasing the average temperatures in july, august and september in 2012; (3) reduction precipitation during the growing season; (4) increasing the number of days with temperatures above $30^{\circ} \mathrm{C}$, in 2012 (70), 2013 (26) and 2014 (35); (5) hydrothermal coefficient, (CH) ranged between 0.59 and 1.57, falling within the limits described in the literature ( 0.7 to 1.8 ), indicating that the moisture was sufficient; (6) Heliothermal real index, (IHr) ranged between 2.0-3.12, higest that the average multiannual 2.31 which shows an increase in thermal resources and optimal ripening of late varieties; (7) oenoclimatic skills index (IAOe) indicates that this area are mainly for the production of red and white wines.

Results also show that the vine cultivated in the vineyard of Dealu Bujorului have a high content of macroelements ('Merlot', 'Cabernet Sauvignon' and also 'Feteasca Neagră') that are very important for human health, copper content are below the limit of detection due to the modern technology for obtaining wines in a controlled manner. This paper gives us new information about the quality of red wines obtained in Dealu Bujorului, Romania.

Acknowledgments. This paper was published under the frame of the Romanian Ministry of Agriculture and Rural Development, project ADER no. 14.2.2. "Quantitative studies on assessment and monitoring contaminants, on the chain of viticulture and winemaking to minimize the amount of pesticides and heavy metals as principal pollutants" and the "Grant of the Romanian National Authority for Scientific Research and Innovation, CCCDI - UEFISCDI, project number 6/2015".

\section{REFERENCES}

1. Avar P, Pour Nikfardjam MS, Kunsági-Máté S, Montskó G, Szabó Z, Böddi K, Ohmacht R, Lázló M (2007). Investigation of phenolic components of Hungarian wines; L Int J Mol Sci 8(10):1028-1038.

2. Bora FD, Pop TI, Bunea CI, Peter A, Nicula C, Urcan DE, Babeș A, Pop N (2014). Physico-mechanical analysis and 
uvological indices at three varieties of grapes for superior white wines grown in north-west Romania. Bulletin UASVM Horticulture 71(2):327-328.

3. Bora FD, Pop TI, Bunea CI, Urcan DE, Babeș A, Cozmuta ML, Cozmuta MA, Pop N (2014)a. Influence of ecoclimatic and ecopedological conditions on quality of white wine grape varieties from North-West of Romania. Bulletin UASVM Horticulture 71(2):218-225.

4. Bora FD, Bunea CI, Rusu T, Pop N (2015). Vertical distribution and analysis of micro-, macroelements and heavy metals in the system soil-grapevine-wine in vineyard from North-West Romania. Chem Cent J 9:1-19.

5. Bora FD, Donici A, Ripanu OM (2016). Compositional quality assessment of wines produced in Silvaniei vine growing center of Simleul Silvaniei, 2013-2015 harvest. Food and Environment Safety 15(1)84-94.

6. Bunea CI (2010). Studies on variability of main productivity and quality characters in a collection of wine varieties concerning their suitability to organic culture technologies and marketing. PhD thesis. UASVM ClujNapoca.

7. Condurso C, Cioncatta F, Tripodi G, Sparacio A, Giglio DMF, Sparla S, Verzera A (2015). Effects of cluster thinning on wine quality of Syrah cultivar (Vitis vinifera L.). Eur Food Res Technol DOI 10.1007/s00217-016-2671-7.

8. Conradie WJ, Carey VA, Bonnardot V, Saayman D, Schoor van LH (2002). Effect of different environmental factors on the performance of Sauvignon blanc grapevines in the Stellenbosch/Durbanville districts of South Africa. I. geology, soil, climate, phenology and grape composition. South African J. Enol. Vitic. 23(2):79-91.

9. Di Paola-Naranjo RD, BaroniMV, Podio NS, RubinsteinHR, FabaniMP, Badini RG, Inga M, Ostera HA, CagnoniM, Gallegos E, Gautier E, Peral-García P, Hoogewerff J, Wunderlin DA (2011). Fingerprints for main varieties of Argentinean wines: terroir differentiation by inorganic, organic, and stable isotopic analyses coupled to chemometrics. J Agric Food Chem 59(14):7854-7865.

10. Fregoni C, Pezzutto $S$ (2000). Principes et premières approches de l'indice bioclimatique de qualité de Fregoni. Progr. Agric. Vitic. 18:390-396.

11. Galet P (1993). Précis de viticulture. Montpellier, Déhan, $582 \mathrm{pp}$.

12. Geana EI, Ionete RI, Tudorache A, Pasa A, Postolache E, Ranca A (2011). Phenolic contents of Romanian wines with different geographical origins. Asian J Chem 23(12):5197-5201.

13. Geana I, Iordache A, Ionete R, Marinescu A, Ranca A, Culea M (2013). Geographical origin identification of Romanian wines by ICP-MS elemental analysis. Food Chem 138(23):1125-1134.

14. Gonçalves da Silva AM, Pavan MA, Muniz AS, Tonin TA, Pilizer $T$ (2008). Nutrient availability in the soil and its absorption, transport, and redistribution in vines. Communications in Soil Science and Plant Analysis 39:1507-1516.
15. Gonzálvez A, Lorens A, Cervera ML, Armenta S, Guardia M (2009). Elemental fingerprint of wines from the protected designation of origin Valencia. Food Chem 112(1):26-34.

16. Huglin P, Schneider C (1998). Biologie et écologie de la vigne. Lavoisier, Paris, 370 pp.

17. Jackson DI, Lombard PB (1993). Environmental and management practices affecting grape composition and wine quality: a review. Am. J. Enol. Vitic. 4:409-430.

18. Jackson RS (2003). Modern biotechnology of winemaking. In: Wine, SM, Pinder R; 2003; editors. Wine. New York: Taylor and Francis. p 228-59.

19. Jackson D, Cherry NJ (1988). Prediction of a district's graperipening capacity, using a latitude-temperature index (LTI). Am. J. Enol. Vitic. 1:19-28.

20. Kliewer WM, Torres RE (1972). Effect of controlled day and night temperatures on grape coloration. Am. J. Enol. Vitic. 2:71-77.

21. Kliewer WM (1973). Berry composition of Vitis vinifera cultivars as influenced by photo and nycto-temperatures during maturation. J. Am. Soc. Hort. Sci. 2:153-159.

22. Meghesan-Breja A, Morar F (2012). Multiresidue analysis of 70 pesticides from soil by gas chromatography-timeof-flight mass spectrometry gc tof $-\mathrm{ms}$. The 6th edition of the Interdisciplinarity in Engineering International Conference "Petru Maior" University of Tîrgu Mures, Romania.

23. Meghesan-Breja A, Cimpoiu C, Hosu A (2014). Multiresidue analysis of pesticides and metabolites from fruits and vegetables by gas chromatography-time-of-flight mass spectrometry. Acta Chromatographica 27(4)657-685. DOI: 10.1556/AChrom.27.2015.4.6

24. Mitic MN, Obradovic MV, Grahovac ZB, Pavlovic AN (2010). Antioxidant capacities and phenolic levels of different varieties of Serbian white wines. Molecules 15(3):20162027.

25. Pop N (2010). General course of viticulture. Ed. Eikon. Cluj-Napoca.

26. Postolache E, Ciubucă A, Bunea CI, Moldovan MP, Nastasia P, Donici A, Bora FD (2016). Research on quality of red wine varieties obtained at Bujoru Vineyard, Dealu Bujorului Wine Center, Romania. AAB Bioflux 8(2):58-76.

27. Riou Ch, Becker N, Sotes Ruiz V, Gomez-Miguel V, Carbonneau A, Panagiotou M, Calo A, Costacurta A, Castro de R, Pinto A, Lopes C, Carneiro L, Climaco P (1994). Le déterminisme climatique de la maturation du raisin: application au zonage de la teneur em sucre dans la communauté européenne. Office des Publications Officielles des Communautés Européennes, Luxembourg, $322 \mathrm{pp}$.

28. Rotaru L, Filipov F, Muste M, Soleru V (2010). Influence of some „Terroir Viticole" factors on quality of grape. Not Bot Agrobot 38(1):176-181.

29. Singleton VL, Esau P (1969). Phenolic substances in grapes and wine, and their significance. Adv. Food Res. Supp. 1: 112-133. 
30. Tonietto J, Carbonneau A (2004). A multicriteria climatic classificationsystem forgrape-growingregions worldwide. Agricultural and Forest Meteorology 124(1-2):81-97. http://dx.doi.org/10.1016/j.agrformet.2003.06.001.

31. Torre GL, Saitta M, Vilasi F, Pellicanò T, Dugo G (2006). Direct determination of phenolic compounds in Sicilian wines by liquid chromatography with PDA and MS detection. Food Chem 94(4):640-650.

32. Târdea C (2007). Chemistry and wine analysis. Publisher "Ion Ionescu de la Brad", Iași, România. 